\title{
Studies on Human Platelet Protease Activity
}

\author{
Ralph L. Nachman and Barbara Ferris \\ From the Department of Medicine, New York Hospital-Cornell Medical \\ Center, New York 10021
}

\begin{abstract}
A в S T R A C T Solubilized protein derived from human platelets was fractionated by DEAE cellulose column chromatography and analyzed for protease activity using three substrates: denatured bovine hemoglobin, alpha casein, and purified plasminogen-free human fibrinogen. A protein fraction was found with proteolytic activity which was heat labile and not attributable to plasmin. The activity was not potentiated by cysteine or inhibited by iodoacetamide. Studies of $\mathrm{pH}$ optima indicated a broad range of enzyme activity with peaks in both the acid and alkaline region. Cathepsin A activity was detected in the platelet protease fraction by hydrolysis of the synthetic substrate $N$-carbobenzoxy- $\alpha$-L-glutamyl-L-tyrosine. Similar proteolytic activity was found when the proteins derived from isolated platelet granules were examined. The results indicate that human platelets possess potent intracellular proteolytic enzymes. The relationship of this proteolytic activity to the hemostatic process is discussed.
\end{abstract}

\section{INTRODUCTION}

Intracellular hydrolytic enzymes in lysosomes are important in the mediation of several cellular functions (1). For example, the lysosomal enzymes released during phagocytosis by polymorphonuclear leukocytes catalyze the digestion of foreign particles and bacteria (2). Human platelets contain intracellular granules which have recently been shown to have many properties similar to classical lysosomes of other cells (3). During the process of formation of the hemostatic plug, there

This work was presented in part at the 52nd Annual Meeting of the Federation of American Societies for Experimental Biology, Atlantic City, 15 April 1968.

Received for publication 3 June 1968 and in revised form 12 July 1968. is eventual disruption and degranulation of the intracellular platelet lysosomes (4). It is logical to assume that intracellular platelet proteases may significantly effect the development as well as the rate of dissolution of the hemostatic platelet plug. To explore further the proteolytic enzyme population of human platelets, we prepared solubilized protein fractions from normal platelets and systematically analyzed them for protease activity. These studies revealed that platelets contain cathepsin A and other nonplasmin proteolytic activities which digest undenatured human fibrinogen. The activity appeared to be associated primarily with proteins derived from the intracellular granules.

\section{METHODS}

Platelets were separated from whole blood and platelet concentrates $^{1}$ as described previously (5). Platelet counts were performed by phase microscopy. Contamination of platelets by leukocytes in multiple samples was less than one cell per 5000 platelets. The isolated platelets were washed 10 times in Alsever's solution (6) and the platelet protein solubilized by ultrasonic vibration (7). The solubilized material was dialyzed extensively against deionized water and lyophilized. Lyophilized platelet protein in most cases was defatted by extraction with chloroform-methanol $(2: 1)$.

Platelet protein was fractionated on $2 \times 25 \mathrm{~cm}$ columns of DEAE ${ }^{2}$ equilibrated with (a) $0.005 \mathrm{M}$ sodium phosphate buffer $\mathrm{pH}$ 7.0. Discontinuous buffer elution was performed with (b) $0.05 \mathrm{M}$ sodium phosphate $\mathrm{pH} 6.0$, (c) $0.05 \mathrm{M}$ sodium phosphate buffer containing $0.05 \mathrm{M}$ $\mathrm{NaCl}, \mathrm{pH} 6.0$, and (d) $0.05 \mathrm{M}$ sodium phosphate containing $0.5 \mathrm{M} \mathrm{NaCl}, \mathrm{pH} 6.0$.

Subcellular platelet fractions obtained by ultracentrifugation were kindly provided by Dr. Aaron Marcus. The preparation and characterization of these fractions have been previously reported (3). Granule, membrane, and "cell sap" protein preparations were obtained as

${ }^{1}$ Kindly provided by The New York Blood Center.

${ }^{2}$ Calbiochem, Los Angeles, Calif. 
previously described (8). These protein solutions were not lyophilized or defatted.

Disc electrophoresis. Acrylamide-gel disc electrophoresis was performed by standard methods at $\mathrm{pH} 8.9$ (9). The composition was as follows: lower gel ( $\mathrm{pH} 8.9$ ) $6.5 \%$ acrylamide, $0.25 \% \quad \mathrm{~N}, \mathrm{~N}^{\prime}$-methylenebisacrylamide, $0.06 \mathrm{M} \mathrm{HCl}, 0.375 \mathrm{~m}$ Tris. Polymerization was performed in the presence of $0.00075 \% \mathrm{~N}, \mathrm{~N}, \mathrm{~N}^{\prime}, \mathrm{N}^{\prime}$-tetramethylethylenediamine and $0.2 \%$ ammonium persulfate; lower buffer ( $\mathrm{pH} 8.1) \quad 0.1 \mathrm{M}$ Tris, $0.05 \mathrm{M} \mathrm{HCl}$; upper gel ( $\mathrm{pH} \quad 7.2) \quad 2.5 \%$ acrylamide, $0.625 \% \quad \mathrm{~N}, \mathrm{~N}^{\prime}$-methylenebisacrylamide, 0.032 м $\mathrm{H}_{3} \mathrm{PO}_{4}, 0.059$ м Tris. Photopolymerization was performed in the presence of $0.00025 \%$ $\mathrm{N}, \mathrm{N}, \mathrm{N}^{\prime}, \mathrm{N}^{\prime}$-tetramethylethylenediamine and $0.0005 \%$ riboflavin; upper buffer ( $\mathrm{pH} 8.9) 0.052 \mathrm{M}$ Tris, $0.0525 \mathrm{M}$ glycine. Samples were applied in $20-\mu 1$ aliquots and adjusted to $50 \mu 1$ with $5 \%$ sucrose. A trace of bromophenol blue marker was added. Electrophoresis was carried out toward the anode at $5 \mathrm{ma} /$ tube for $45 \mathrm{~min}$. The gels were stained with either aniline blue black or Coomassie Blue (10).

Coagulation studies. Thrombin times were performed by incubating $200 \mu \mathrm{l}$ of $0.5 \%$ plasminogen-free fibrinogen ${ }^{3}$ in buffered saline $(\mathrm{NaCl} 0.15 \mathrm{M}$, Tris $0.01 \mathrm{~m} \mathrm{pH}$ 7.5), $50 \mu \mathrm{l}$ buffered saline, and $50 \mu \mathrm{l}$ test reagent for 10 $\mathrm{min}$ at room temperature. At the end of the incubation period, $100 \mu \mathrm{l}$ of bovine thrombin 4 (2 NIH units/ml) was added and the clotting time observed. The assays were also carried out in the presence of epilson aminocaproic acid, ${ }^{5}$ soybean trypsin inhibitor, ${ }^{6}$ and pancreatic trypsin inhibitor. ${ }^{6}$ Reptilase clotting times were similarly performed using $100 \mu \mathrm{l}$ of reptilase $7(1 \mathrm{KU} / \mathrm{ml})$. $\mathrm{Pa}$ pain ${ }^{6}$ clotting times were also performed in an identical system using $100 \mu 1$ papain $(26 \mu \mathrm{g} / \mathrm{ml})$. The end point in the papain system was noted as coarse flocculation rather than overt clot formation. Plasmin 8 was kindly supplied by Dr. Peter Harpel. All coagulation tests were performed in duplicate.

Enzyme assays. Three protein substrates were utilized to study the enzymatic spectrum of the active platelet fraction. These included bovine hemoglobin, ${ }^{9}$ plasminogen-free fibrinogen, and alpha casein. ${ }^{6}$ Two systems were used to test for enzymatic activity. In one, the enzyme and substrate were incubated for a given period of time in an optimal $\mathrm{pH}$ and ionic environment. Aliquots of the mixture were then analyzed by acrylamide gel electrophoresis. In the second system release of tyrosine-containing fragments into the protein-free supernate was measured after enzyme substrate interaction. Enzyme inhibition studies were performed in the presence of soybean trypsin inhibitor and pancreatic trypsin inhibitor.

${ }^{3}$ Lot No. S4268 Mann Fine Chemicals, Inc., N. Y.

4 Parke, Davis \& Co., Detroit, Mich.

5 American Cyanamid, Pearl River, N. Y.

6 Worthington Biochemical Corp., Freehold, N. J.

${ }^{7}$ Kindly provided by Pentapharm A. G., Basel, Switzerland. Supplied as Klobusitsky units (KU) per milliliter.

${ }^{8}$ Supplied as $32.3 \mathrm{MDH} \mathrm{cu} / \mathrm{ml}$ in $50 \%$ glycerol.

${ }^{9}$ Sigma Chemical Co., St. Louis, Mo.
Cathepsin activity. This was measured as described by Anson (11). Bovine hemoglobin substrate ( $2 \times$ crystallized) was denatured by incubation of a $2 \%$ solution in $0.15 \mathrm{M}$ lactate buffer $\mathrm{pH} 3.6$ for $1 \mathrm{hr}$ at $37^{\circ} \mathrm{C}$. For analysis in the acrylamide-gel system, $100 \mu 1$ of denatured hemoglobin $(1 \mathrm{mg} / \mathrm{ml})$ was incubated for $1 \mathrm{hr}$ at $37^{\circ} \mathrm{C}$ with $150 \mu \mathrm{l}$ of the lactate buffer and $50 \mu \mathrm{l}$ of enzyme or control solution. A $20 \mu \mathrm{l}$ aliquot was subsequently analyzed by acrylamide-gel electrophoresis. Assay mixtures of the chromatographically isolated platelet protein fractions as well as subcellular fractions contained the following: $1.9 \mathrm{ml}$ substrate, $50 \mu \mathrm{l}$ sample $(1 \mathrm{mg} / \mathrm{ml})$, and $50 \mu 1$ buffer. Duplicate samples were incubated for $1 \mathrm{hr}$ at $37^{\circ} \mathrm{C}$, and the reaction was stopped with $5 \mathrm{ml}$ of $5 \%$ trichloroacetic acid (TCA). TCA was added at zero time to the control incubations. Additional controls included mixtures of substrate and buffer in the absence of enzyme incubated for $1 \mathrm{hr}$ at $37^{\circ} \mathrm{C}$. After TCA precipitation, the mixtures were left at room temperature for $10 \mathrm{~min}$ and centrifuged at $3000 \mathrm{~g}$ for $15 \mathrm{~min}$. Tyrosine equivalents $(\mu \mathrm{M})$ were determined in $1 \mathrm{ml}$ aliquots of the TCA supernate by the Folin method (12) using tyrosine as a standard.

pH optima studies were performed similarly; however, the substrate bovine hemoglobin was dissolved in 6 M deionized urea in universal buffer of different $\mathrm{pH}$ ranges (13). The concentration of the universal buffer was $100 \mathrm{~mm}$ with respect to each of the four contributory salts (citrate, phosphate, Tris, and carbonate).

Caseinolytic activity. For analysis by the acrylamidegel system, $100 \mu \mathrm{l}$ of alpha casein, $1.4 \%$ in Tris saline

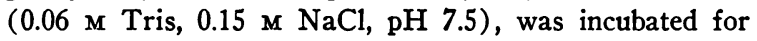
$1 \mathrm{hr}$ at $37^{\circ} \mathrm{C}$ with $50 \mu \mathrm{l}$ of the platelet protein solution $(1 \mathrm{mg} / \mathrm{ml}$ ) and $150 \mu \mathrm{l}$ of Tris saline buffer. A $20 \mu \mathrm{l}$ aliquot was subsequently analyzed by acrylamide-gel electrophoresis. In the second system, assays for caseinolytic activity of platelet protein fractions included 2.5 $\mathrm{ml}$ of alpha casein (1.4\%) in Tris saline, $50 \mu \mathrm{l}$ enzyme solution, and $2.45 \mathrm{ml}$ of Tris saline buffer. The solution was mixed and $2.0 \mathrm{ml}$ was transferred into $3.0 \mathrm{ml}$ of 0.5 M perchloric acid for the zero blank. The remainder of the solution was incubated at $37^{\circ} \mathrm{C}$ for $30 \mathrm{~min} .2 \mathrm{ml}$ was then transferred to $3.0 \mathrm{ml}$ of perchloric acid. The samples were mixed and placed at room temperature for $30 \mathrm{~min}$ and then centrifuged at $3000 \mathrm{~g}$ for $15 \mathrm{~min}$. The optical density of the clear supernate at $275 \mathrm{~m} \mu$ was then recorded. One $\mathrm{CTA}^{10}$ unit corresponds to the liberation of $10 \mu \mathrm{g}$ or $0.055 \mu \mathrm{M}$ of tyrosine per min. $137 \mu \mathrm{g}$ of tyrosine $/ \mathrm{ml}$ in $0.3 \mathrm{M}$ perchloric acid gives an optical density of 1.00 at $275 \mathrm{~m} \mu$. Therefore CTA units in the assay were equal to net

$$
\frac{\text { oD } \times 137 \times 2.5 \times 5}{30 \times 10} \text {. }
$$

For $\mathrm{pH}$ optima studies, the substrate alpha casein was dissolved in $6 \mathrm{M}$ deionized urea in universal buffer at various $\mathrm{pH}$ ranges.

Fibrinogenolytic activity. For analysis by the acrylamide-gel system $100 \mu \mathrm{l}$ of plasminogen-free fibrinogen

${ }^{10} \mathrm{NIH}$ Committee on Thrombolytic Activity. 
$\left(0.5 \%\right.$ in buffered saline) was incubated for $1 \mathrm{hr}$ at $37^{\circ} \mathrm{C}$ with $50 \mu 1$ of platelet protein solution $(1 \mathrm{mg} / \mathrm{ml})$ and $150 \mu 1$ of buffered saline. A $20 \mu 1$ aliquot was subsequently analyzed by disc electrophoresis. In the second system, assay mixtures of the platelet protein fractions contained the following: $1.9 \mathrm{ml}$ substrate, $50 \mu 1$ platelet enzyme solution, and $50 \mu 1$ buffer. Duplicate samples were incubated for $1 \mathrm{hr}$ at $37^{\circ} \mathrm{C}$ and the reaction was stopped with $5 \mathrm{ml}$ of $5 \%$ TCA. TCA was added at zero time to the control incubations. Control mixtures included substrate and buffer incubated in the absence of enzyme for $1 \mathrm{hr}$ at $37^{\circ} \mathrm{C}$. After TCA precipitation, the mixtures were left at room temperature for $10 \mathrm{~min}$ and centrifuged at $3000 \mathrm{~g}$ for $15 \mathrm{~min}$. Tyrosine equivalents were determined as described above for cathepsin activity. $\mathrm{pH}$ optima studies on fibrinogen were performed as previously mentioned except that the substrate was dissolved in the $\mathrm{Na}_{2} \mathrm{HPO}_{-}-$ citric acid buffer system of McIlvaine (14) at selected $\mathrm{pH}$ ranges.

Determination of the Michaelis constants. Michaelis constants were determined for the three protein substrates alpha casein, fibrinogen, and bovine hemoglobin. Experiments utilizing casein and fibrinogen were performed in tris saline $\mathrm{pH} 7.5$ at $37^{\circ} \mathrm{C}$ for $1 \mathrm{hr}$. The bovine hemoglobin substrate was incubated in $0.15 \mathrm{M}$ lactate buffer $\mathrm{pH} 3.6$ at $37^{\circ} \mathrm{C}$ for $1 \mathrm{hr}$. The velocity of the individual reactions was measured by determining the quantity of material formed which was no longer precipitated with TCA. A constant quantity of the platelet enzyme solution was added to increasing amounts of the various substrates. The Michaelis constants were calculated by the graphic method of Lineweaver and Burk (15) relating the reciprocal of the velocity of the reaction to the reciprocal of the substrate concentration.

Effects of various agents on platelet proteolytic activity. The proteolytic activity of the platelet enzyme solution on the three substrates was determined as described above in the presence of cysteine $(0.005 \mathrm{M})$ and iodoacetamide $(0.005 \mathrm{M})$. In addition, the proteolytic effect of the platelet enzyme solution on alpha casein and fibrinogen was determined in the presence of $\mathrm{Zn}^{++}, \mathrm{Fe}^{++}$, and $\mathrm{Mn}^{++}$ in separate experimentr The final concentration of metal ions in each incubation mixture was $1 \times 10^{-8} \mathrm{M}$. The salts used were supplied as zinc acetate, ferrous sulfate, and manganous chloride.

Assays with synthetic substrates. Cathepsin A activity was determined with $N$-carbobenzoxy- $\alpha$-L-glutamyl-L tyrosine (CBZ-glu-tyr).11 Substrates were solubilized by gentle heating at a concentration of $0.05 \mathrm{M}$ in sodium citrate buffer $\mathrm{pH} 5.0,0.1 \mathrm{M}$ as described by Tallan, Jones, and Fruton (16). The assay included $1.0 \mathrm{ml}$ substrate and $100 \mu \mathrm{l}$ platelet protein solution $(1 \mathrm{mg} / \mathrm{ml})$. Incubation was carried out at $37^{\circ} \mathrm{C}$ for $16 \mathrm{hr}$. Control mixtures included the substrate and platelet protein mixture previously heated to $60^{\circ} \mathrm{C}$ for $15 \mathrm{~min}$ and substrate alone. Isolated platelet granule protein was also tested in this system. At the conclusion of the incubation period the mixtures were lyophilized. Free amino acid release was determined

11 Cyclo Chemicals Corp., Los Angeles, Calif. by descending paper chromatography of $100-\mu 1$ aliquots of the reaction mixture using the upper layer of a butanol: acetic acid: water $(4: 1: 5)$ mixture. Similar assays for cathepsin B using benzoyl L-arginine ethyl ester 11 and for cathepsin $\mathrm{C}$ using $N$-acetyl-L-tyrosine ethyl ester ${ }^{11}$ as substrates were performed as described by Wasi, Murray, Macromoue, and Movat (17).

Purified human urokinase 12 was kindly provided by Dr. Peter Harpel.

Immunodiffusion and immunoelectrophoresis studies were performed as previously reported $(18,19)$. Antihuman platelet protein was prepared as described (7). Anti-albumin and anti-prealbumin were obtained commercially. ${ }^{13}$

\section{RESULTS}

Characterization of the platelet protein fractions. The platelet protein was fractionated into four separate major peaks following chromatography on DEAE cellulose. A typical separation is shown in Fig. 1. Repeated chromatographic separations of different batches of platlet protein revealed essentially identical patterns. One batch of platelet protein was processed omitting the defatting step of chloroform methanol extraction. Chromatography of this sample was essentially similar to the pattern obtained with defatted specimens except for slight diminution of the material eluted in peak 1 . Material from each major peak was pooled, ultrafiltered, and dialyzed against buffered saline. Acrylamide-gel electrophoresis of the peaks 1, 2, and 4 is shown in Fig. 1. No bands were seen when concentrates from peak 3 were analyzed. Peak 1 was the most heterogeneous revealing seven to eight bands. Two major bands were seen in peak 2. Peak 4 which was subsequently shown to contain platelet protease activity had two fast moving bands, and was studied in greatest detail.

Immunoelectrophoresis of peak 4 revealed two platelet protein components, one of which reacted with an antiserum monospecific for serum albumin (Fig. 2). The second component in peak 4 reacted with an anti-platelet protein serum absorbed with lyophilized human plasma. Of interest was the splitting of the platelet albumin line when antiplatelet serum was used as the developing antiserum. No precipitin reaction was observed when peak 4 was reacted against an antiserum specific for serum prealbumin.

12 Lot 762-8946. 25,000 units/ml in saline. Abbott Laboratories Ltd. Queensborough, Kent, England.

13 Lloyd Bros., Inc., Cincinnati, Ohio. 


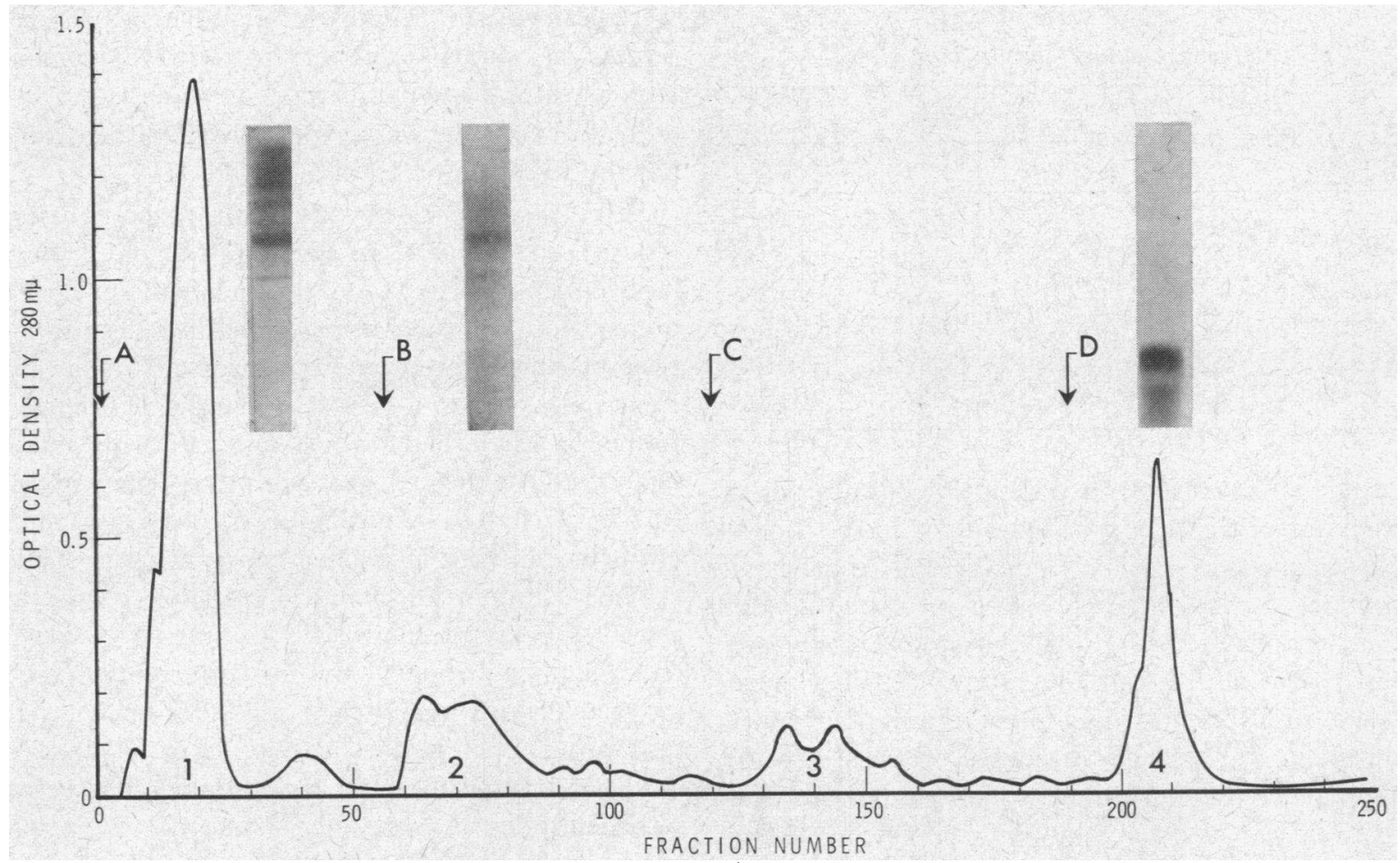

FIGURE 1 Chromatography of solubilized platelet proteins. $180 \mathrm{mg}$ of material was applied to the column. Arrows indicate sequence of eluting buffers: $(A) 0.005 \mathrm{M}$ sodium phosphate buffer $\mathrm{pH} 7.0 ;(B) 0.05 \mathrm{M}$ sodium phosphate $\mathrm{pH}$ $6.0 ;(C) 0.05 \mathrm{M}$ sodium phosphate buffer containing $0.05 \mathrm{MNaCl} \mathrm{pH} 6.0 ;(D) 0.05 \mathrm{M}$ sodium phosphate containing 0.5 $\mathrm{M} \mathrm{NaCl}, \mathrm{pH}$ 6.0. The major protein peaks were pooled and analyzed by disc electrophoresis.

Coagulation studies. The effect of the four platelet protein fractions on the clotting of purified human plasminogen-free fibrinogen was tested using several enzyme systems.

Enzyme clotting times. Fibrinogen was incubated with buffer and test reagent for $10 \mathrm{~min}$, bovine thrombin, papain, or reptilase was added, and the time of clot formation recorded. Table I shows a typical experiment in which the averages of du- plicate determinations are given. No significant prolongation of the thrombin, papain, or reptilase clotting time was noted in the presence of serum albumin, peak 1,2 , or 3 . No clot was seen after 10 min observation following incubation with peak 4. In these, as well as subsequent studies, albumin, peaks $1,2,3$, and 4 were adjusted to equal protein concentrations, generally in the range of 1 $\mathrm{mg} / \mathrm{ml}$, and dialyzed into buffered saline.

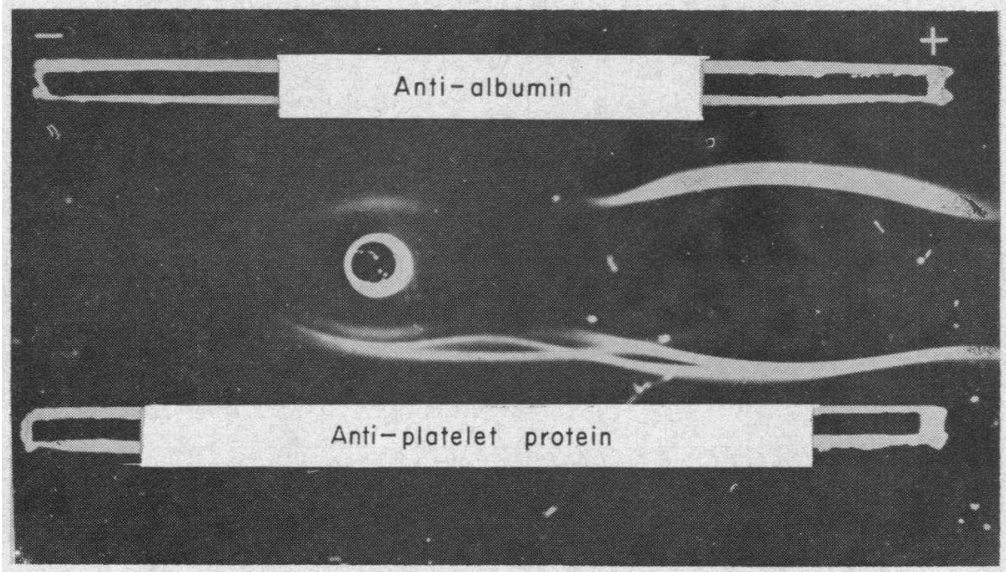

FIGURE 2 Immunoelectrophoresis of peak 4 at protein concentration of $1 \mathrm{mg} / \mathrm{ml}$. 
TABLE I

Enzyme Clotting Times of Fibrinogen

\begin{tabular}{lrrr}
\hline & \multicolumn{3}{c}{ Time } \\
\cline { 2 - 4 } Test reagent & Thrombin & Papain & Reptilase \\
\hline Buffer & 35 & 80 & 160 \\
Albumin & 37 & 94 & 180 \\
Peak 1 & 41 & 108 & 184 \\
Peak 2 & 36 & 84 & 150 \\
Peak 3 & 35 & 87 & 150 \\
Peak 4 & $>600$ & $>600$ & $>600$ \\
\hline
\end{tabular}

The effect of soybean trypsin inhibitor, a potent inhibitor of plasmin, was determined in the thrombin time system (Table II). The test reagent and soybean trypsin inhibitor were incubated for 15 min at room temperature. Buffer and fibrinogen were then added and the mixture further incubated for $10 \mathrm{~min}$ at room temperature, after which thrombin was added. The times recorded are the averages of duplicate determinations. In this system soybean trypsin inhibitor completely blocked the proteolytic effect of plasmin whereas no inhibitory effect on peak 4 was noted. These studies were repeated using soybean trypsin inhibitor at a concentration of $5 \mathrm{mg} / \mathrm{ml}$. No inhibitory effect on peak 4 was demonstrable. An identical system was utilized to study the effect of pancreatic trypsin inhibitor $(1 \mathrm{mg} / \mathrm{ml})$. Identical results were obtained; there was complete inhibition of plasmin action but no effect on peak 4 activity. . Epsilon amino-caproic acid $\left(1 \times 10^{-2} \mathrm{M}\right)$ similarly did not inhibit peak 4 activity. Enzyme clotting time studies

TABLE II

Effect of Soybean Trypsin Inhibitor on Thrombin Times*

\begin{tabular}{lc}
\hline \multicolumn{1}{c}{ Test reagent } & Time (sec) \\
\hline Buffer & 39 \\
Plasmin $(1 / 2$ unit $/ \mathrm{ml}) \ddagger$ & 600 \\
Plasmin $(1 / 2$ unit $/ \mathrm{ml})$ & 41 \\
Peak 1 & 44 \\
Peak 2 & 40 \\
Peak 3 & 38 \\
Peak 4 & 600
\end{tabular}

* The incubation system included $200 \mu \mathrm{l}$ of $0.5 \%$ fibrinogen, $25 \mu \mathrm{l}$ buffer, $25 \mu \mathrm{l}(1 \mathrm{mg} / \mathrm{ml})$ soybean trypsin inhibitor, $50 \mu \mathrm{l}$ test reagent, and $100 \mu \mathrm{l}(2$ units $/ \mathrm{ml})$ thrombin. $\ddagger$ Soybean trypsin inhibitor omitted from the incubation ststem. were performed with four different batches of peak 4 material ; similar inhibitory activity was demonstrated with all preparations.

Peak 4 activity was completely abolished after heating to $60^{\circ} \mathrm{C}$ for $15 \mathrm{~min}$ (Table III).

Disc electrophoresis evaluation of the proteolytic effect of peak 4 on fibrinogen. The proteolytic effect of peak 4 on the purified fibrinogen preparation was demonstrated by disc electrophoresis of substrate enzyme mixtures after $1 \mathrm{hr}$ incubation at $37^{\circ} \mathrm{C}$ (Fig. 3). Purified fibrinogen formed a single band which migrated only minimally into the gel. Progressive proteolytic activity was demonstrated by incubating a constant amount of fibrinogen with increasing concentrations of the enzyme solution. Maximum digestion occurred at a peak 4 concentration of $1.3 \mathrm{mg} / \mathrm{ml}$ (Fig. 3, gel $3)$. Prior incubation of the enzyme solution with soybean trypsin inhibitor $(1 \mathrm{mg} / \mathrm{ml})$ did not significantly inhibit peak 4 activity (Fig. 3, gel 4). Soybean trypsin inhibitor was also ineffective at a concentration of $5 \mathrm{mg} / \mathrm{ml}$. The anodal migrating bands in the peak 4-treated fibrinogen were identical to electrophoresed peak 4 alone. No protease activity in this system was detected by incubating fibrinogen with serum albumin, or peaks 1,2 , or 3 .

Differential effects of plasmin and peak 4 on fibrinogen. The proteolytic products of fibrinogen after plasmin action differed from those observed after proteolysis by peak 4 (Fig. 4, gels 1 and 2). Four to five well-defined split products were observed following exposure to peak 4. A slower moving dense band in the peak 4 split products appeared to have no counterpart in the plasmin split products. This was true using plasmin at three concentration ranges: $0.5,0.25$, and 0.12 units $/ \mathrm{ml}$. The fast moving anodal band seen fol-

TABLE III

Thrombin Time: Effect of Heating Test Reagents*

\begin{tabular}{cc}
\hline Test reagent & Time (sec) \\
\hline Buffer & 38 \\
Peak 1 & 42 \\
Peak 2 & 34 \\
Peak 3 & 35 \\
Peak 4 & 36
\end{tabular}

* The incubation system included $200 \mu 1$ of $0.5 \%$ fibrinogen, $50 \mu$ l buffer, $50 \mu$ l test reagent heated to $60^{\circ} \mathrm{C}$ for $15 \mathrm{~min}$, and $100 \mu \mathrm{l}$ thrombin ( 2 units $/ \mathrm{ml}$ ). 

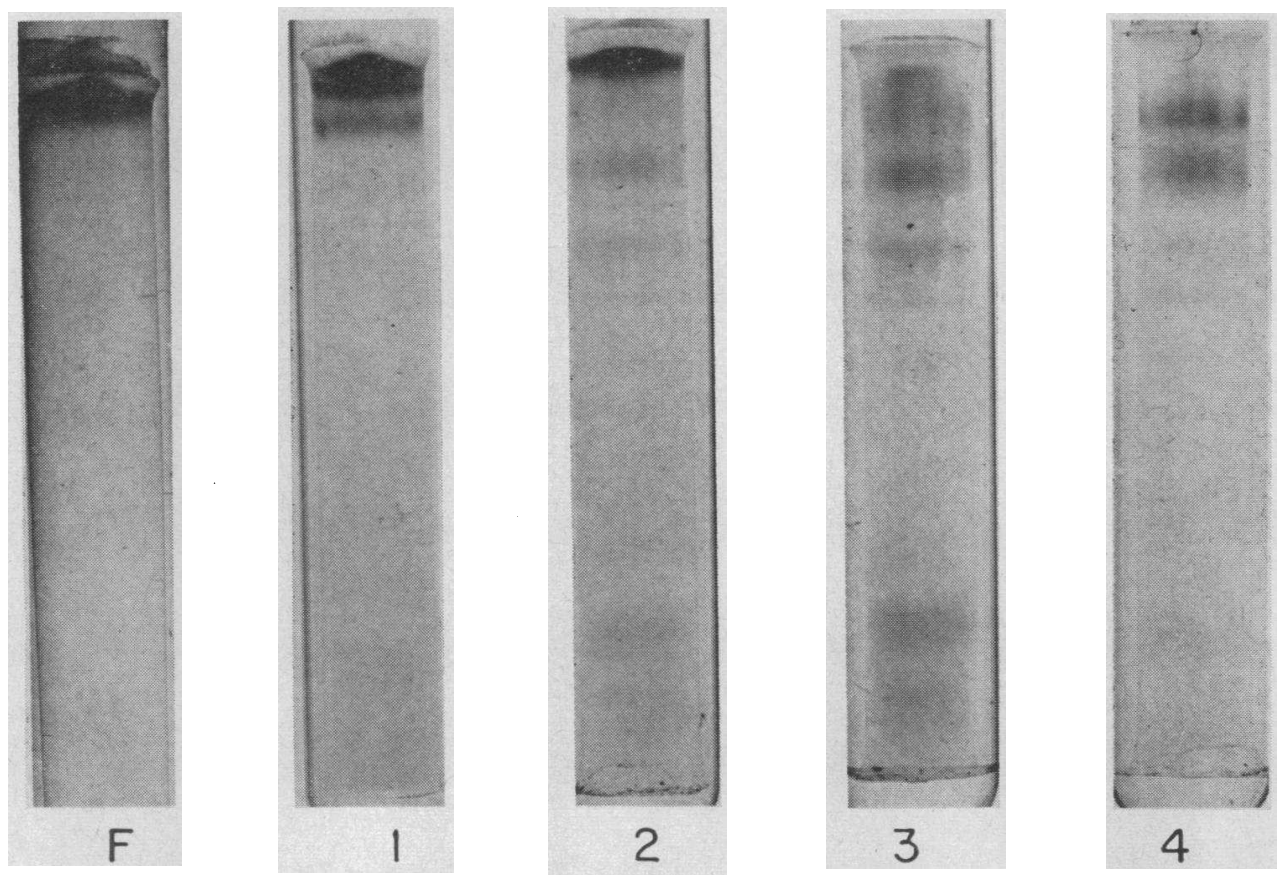

FIGURE 3 Progressive proteolysis of fibrinogen with increasing amounts of peak 4. Acrylamide-gel electrophoresis of $(F)$ fibrinogen $(0.5 \%) ;(1)$ fibrinogen plus peak $4(0.2 \mathrm{mg} / \mathrm{ml})$; (2) fibrinogen plus peak $4(0.5 \mathrm{mg} / \mathrm{ml})$; (3) fibrinogen plus peak $4(1.3 \mathrm{mg} / \mathrm{ml})$; (4) fibrinogen plus peak $4(1 \mathrm{mg} / \mathrm{ml})$ previously incubated with soybean trypsin inhibitor $(1 \mathrm{mg} / \mathrm{ml})$. Anode is at the bottom.

lowing plasmin was not observed using peak 4 in concentration ranges of $1-5 \mathrm{mg} / \mathrm{ml}$. Plasmin action was completely blocked by pancreatic trypsin inhibitor while no inhibitory effect was noted on the proteolytic activity of peak 4 (Fig. 4, gels 3 and 4). Peak 4 was also not inhibited at a pancreatic trypsin inhibitor concentration of $5 \mathrm{mg} / \mathrm{ml}$.

Lack of effect of urokinase on the fibrinogen preparation. To rule out the possibility that peak 4 proteolytic activity resulted from activation of contaminating plasminogen in the fibrinogen preparation, we performed incubation studies with urokinase. Fibrinogen $(100 \mu \mathrm{l}, 0.5 \%)$ was added to buffered saline $(150 \mu \mathrm{l})$ and urokinase $(50 \mu \mathrm{l}$, 125 units) for $1 \mathrm{hr}$ at $37^{\circ} \mathrm{C}$. No evidence of plasminogen activation and subsequent fibrinogen proteolysis was demonstrable on gel electrophoresis. In addition, aliquots of the urokinase-incubated fibrinogen had no effect on the thrombin clotting time of a fibrinogen solution.

Cathepsin and caseinolytic activity of peak 4. Peak 4 was shown to have significant cathepsin activity as defined by hydrolysis of denatured bovine hemoglobin at acid $\mathrm{pH}$ (Fig. 5). This activity was not inhibited by soy bean trypsin inhibitor or pancreatic trypsin inhibitor. Caseinolytic activity of peak 4 was similarly demonstrated by incubation of alpha casein with the enzyme solution at $\mathrm{pH}$ 7.5. Neither cathepsin nor caseinolytic activity was demonstrable in these systems when peak 1 , 2 , or 3 were used.

pH optima studies. $\mathrm{pH}$ optima curves of peak 4 were constructed using the three substrates: denatured bovine hemoglobin, alpha casein, and human fibrinogen. Different batch preparations of peak 4 from separate DEAE chromatographic separations were utilized in these studies. However, the electrophoretic, immunologic, and thrombin time prolongation properties of the separate enzyme preparations were similar in all cases. Maximum hydrolytic activity on fibrinogen was observed in the range of $\mathrm{pH} 6.0$ to $\mathrm{pH} 8.0$ (Fig. $6)$. Optimum activity against the denatured hemoglobin substrate was maximal in the range from $\mathrm{pH} 6.5$ to $\mathrm{pH}$ 7.8. Two caseinolytic peaks of activity were noted, one in the acid range of $\mathrm{pH} 4.8$ and one in the alkaline range of $\mathrm{pH} 8.4$.

Enzyme kinetic studies. A study of the enzy- 

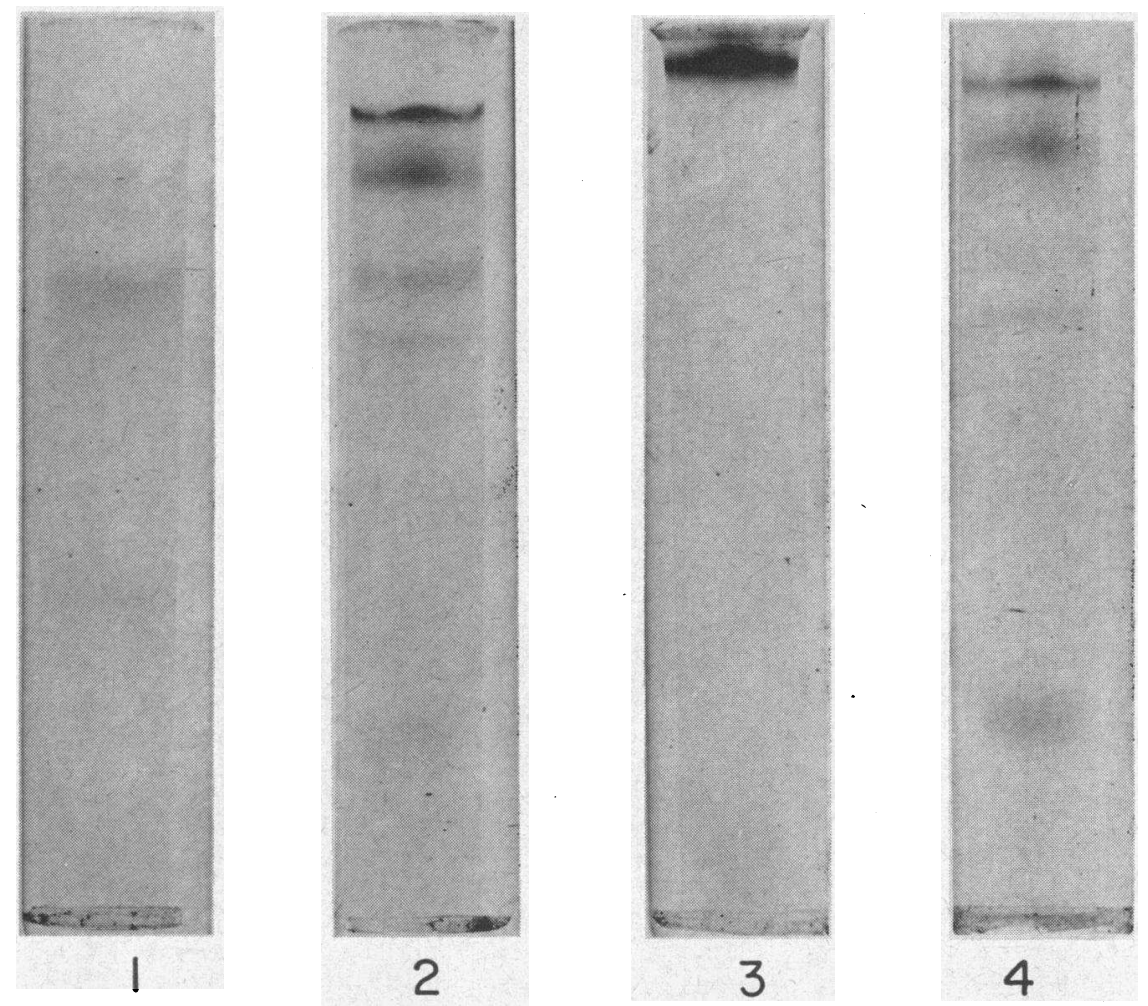

FIGURE 4 Differential effect of plasmin and peak 4 on fibrinogen. Acrylamide-gel electrophoresis of (1) fibrinogen plus plasmin $(1 / 2$ unit $/ \mathrm{ml})$, (2) fibrinogen plus peak $4(1 \mathrm{mg} / \mathrm{ml})$, (3) fibrinogen plus plasmin previously incubated for $15 \mathrm{~min}$ with pancreatic trypsin inhibitor $(1 \mathrm{mg} / \mathrm{ml})$, (4) fibrinogen plus peak 4 previously incubated for $15 \mathrm{~min}$ with pancreatic trypsin inhibitor $(1 \mathrm{mg} / \mathrm{ml})$. Anode is at the bottom.

matic reactions with a constant amount of peak 4 solution and increasing amounts of casein, fibrinogen, or bovine hemoglobin in separate experiments showed that the reactions generally followed Michaelis-Mentin kinetics. The experimental points obtained when plotted according to Lineweaver and Burk (15) corresponded in each case to a straight line. A kinetic study utilizing alpha casein at $\mathrm{pH} 7.5$ in tris saline is shown in Fig. 7. The molecular weight of alpha casein was assumed to be 375,000 (20). The $K_{m}$ was $5.2 \times 10^{-6} \mathrm{M}$. Two separate experiments utilizing different batches of peak 4 (one of which was not defatted) resulted in essentially identical $K_{m}$ values. Similar experiments were performed using plasminogenfree fibrinogen at $\mathrm{pH} 7.5$ in tris saline and bovine hemoglobin at $\mathrm{pH} 3.6$ in $0.15 \mathrm{M}$ lactate buffer. $K_{m}$ for fibrinogen was $8.3 \times 10^{-6} \mathrm{M}$. The $K_{m}$ for hemoglobin was $2.3 \times 10^{-4} \mathrm{M}$.

Effects of various agents on proteolytic activity of peak 4. To define more precisely the nature of the enzyme(s) in the peak 4 solution, we measured proteolytic activity on the three substrates in the presence of cysteine, iodoacetamide, and various metals. Cysteine and iodoacetamide did not significantly affect the proteolytic activity of the enzyme preparation. $\mathrm{Zn}^{++}, \mathrm{Fe}^{++}$, and $\mathrm{Mn}^{++}$at concentrations of $1 \times 10^{-3} \mathrm{M}$ likewise did not potentiate the proteolytic activity of peak 4 solutions against alpha casein and fibrinogen in the alkaline range of $\mathrm{pH} 7.5$.

Enzymatic activity of the proteins derived from platelet subcellular fractions. Solubilized proteins derived from subcellular fractions of human platelets from one donor were assayed using the three substrates. Significant proteolytic activity was demonstrable primarily in the material obtained from the granule fraction. This preparation hydrolyzed fibrinogen as well as casein at $\mathrm{pH} 7.5$. In addition, cathepsin activity was demonstrable against the hemoglobin substrate at $\mathrm{pH} 3.5$ (Fig. 8). 


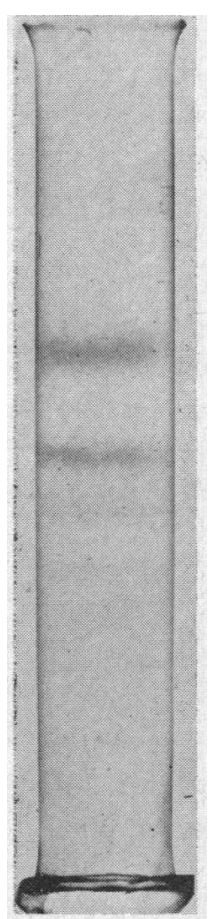

Figure 5 Cathepsin activity of peak 4. Acrylamide-gel electrophoresis of (left) denatured bovine hemoglobin ( $1 \mathrm{mg} / \mathrm{ml}$ ) $100 \mu \mathrm{l}$ plus buffer $50 \mu \mathrm{l}$, (right) denatured bovine hemoglobin $(1 \mathrm{mg} / \mathrm{ml}) 100 \mu \mathrm{l}$ plus peak $4(0.5$ $\mathrm{mg} / \mathrm{ml}) 50 \mu \mathrm{l}$. As can be seen the two major bands representing bovine hemoglobin (left) have disappeared following enzymatic digestion. Anode is at the bottom.

Enzymatic activity toward synthetic substrates. To study the nature of the specific cathepsin(s) present in the peak 4 preparation, we incubated the enzyme solution with CBZ-glu-tyr. The mixtures

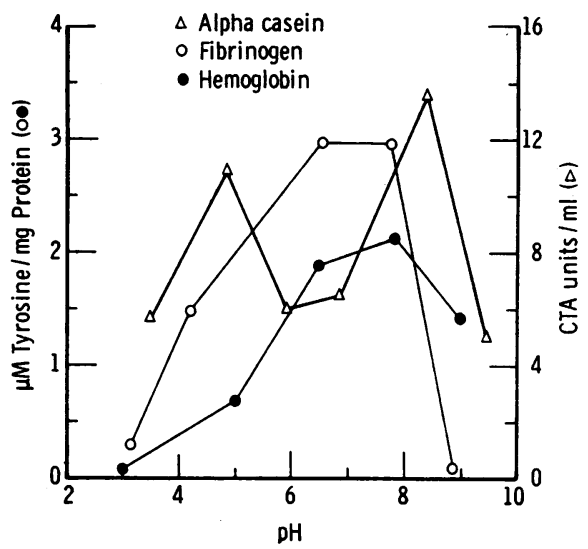

FIgURE $6 \mathrm{pH}$ optima studies of peak 4 enzyme solution and alpha casein $\triangle-\triangle$, fibrinogen $O-O$, and denatured hemoglobin - - CTA units on the right refer to standard caseinolytic units as defined by NIH Committee on Thrombolytic Act:vity.

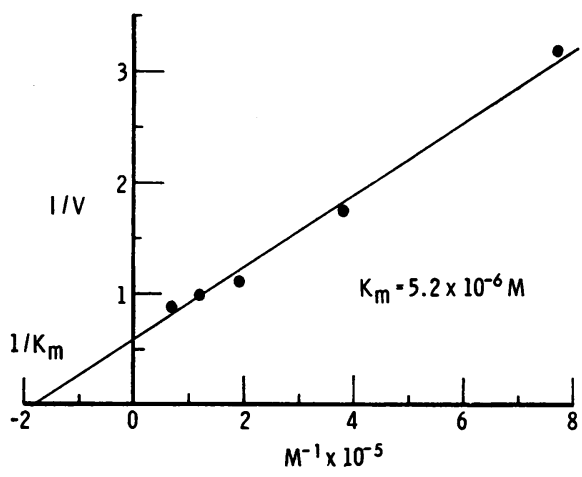

FIGURE 7 Graphic representation according to Lineweaver and Burk for determination of the Michaelis constant of peak 4 solution $(1 \mathrm{mg} / \mathrm{ml})$ using alpha casein as substrate. $V$ equals $\mathrm{mg}$ tyrosine released per min per $\mathrm{ml}$ enzyme solution. Molecular weight of alpha casein was assumed to be $375,000 . K_{m}$ is $5.2 \times 10^{-6} \mathrm{M}$.

were lyophilized and free amino acid release was determined by descending paper chromatography. In three separate experiments using different batches of peak 4 solution, tyrosine was released from the CBZ-glu-tyr substrate. Protein solutions prepared from isolated platelet granules at concentrations of $1 \mathrm{mg} / \mathrm{ml}$ similarly released free tyrosine in two separate experiments. No cathepsin B activity was demonstrated using peak 4 and benzoyl L-arginine ethyl ester as substrate. Similarly no cathepsin $\mathrm{C}$ activity was demonstrated using peak 4 and $N$-acetyl-L-tyrosine ethyl ester as substrate.

\section{DISCUSSION}

These studies demonstrate protease activity in a specific fraction chromatographically isolated from

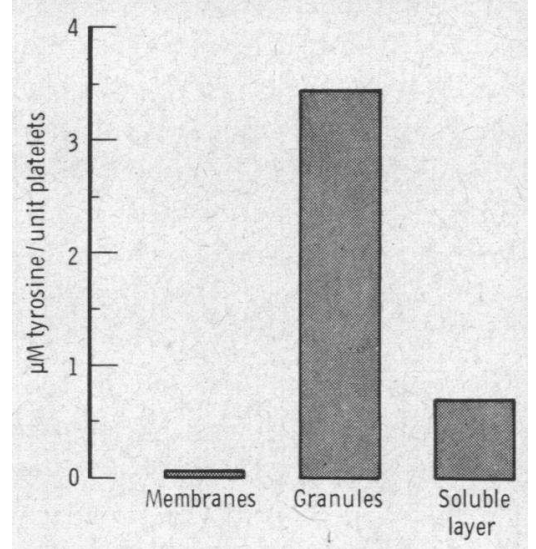

FIGURE 8 Cathepsin activity of soluble protein derived from subcellular platelet fractions obtained from one unit of whole blood. 
a mixture of solubilized platelet proteins. Peak 4 prolonged the thrombin clotting times of purified fibrinogen solutions. This effect did not appear to reflect direct antithrombin activity as evidenced by the equally significant prolongation of the reptilase and papain clotting times. Direct fibrinogen hydrolysis was demonstrated using the acrylamide gel system. Fibrinogen was split into four to five smaller subunits with release of measurable tyrosine into the protein-free supernate. These findings raised the possibility that the proteolytic activity in peak 4 might be related to the generation of plasmin, particularly since plasminogen proactivator, as well as plasminogen, has been previously demonstrated to be associated with platelets (21, 7 ). To rule out this possibility, we compared the protease activity of the peak 4 material to the welldescribed enzymatic properties of plasmin. Peak 4 was not affected by soy bean trypsin inhibitor or pancreatic trypsin inhibitor, agents known to block the action of plasmin (22). In addition, peak 4 was completely inactivated by heating to $60^{\circ} \mathrm{C}$ for 15 min. Peak 4 was not inhibited by epsilon aminocaproic acid, an inhibitor of plasminogen activation. The proteolytic subunits (split products) formed by the action of purified plasmin on the fibrinogen substrate differed significantly from the subunits formed after peak 4 proteolytic activity. These studies were carried out over wide ranges of enzyme concentration. In no instance were identical proteolytic split products formed. To further rule out the possibility that peak 4 enzymatic activity reflected activation of contaminating plasminogen in the fibrinogen preparation, we incubated fibrinogen substrates with purified urokinase, an activator of human plasminogen. No split products were observed by acrylamide-gel electrophoresis of the urokinase-incubated fibrinogen and no inhibitors of thrombin clotting were detected in the fibrinogen-treated solution. For these reasons it appeared unlikely that the proteolytic activity of peak 4 was related to the plasmin system.

Cathepsin activity was detected in the peak 4 preparations by the hydrolysis of denatured bovine hemoglobin at acid $\mathrm{pH}$. Peak 4 cathepsin activity extended over a relatively broad $\mathrm{pH}$ range with maximal activity at $\mathrm{pH}$ 6.5-7.8. This range of $\mathrm{pH}$ optimal activity has been observed with some cathepsins previously studied (23). How- ever, most of the cathepsin group of enzymes appears to have maximal activity in the acid $\mathrm{pH}$ ranges $(24,25,26)$. Cathepsins have been defined as intracellular proteinases which are distinct from the well-known protein splitting enzymes such as pepsin and trypsin which are secreted into the mammalian gastrointestinal tract (23). Five well-defined cathepsins have been studied in various animal tissues and are referred to as cathepsins $\mathrm{A}, \mathrm{B}, \mathrm{C}, \mathrm{D}$, and $\mathrm{E}$. These enzymes have been primarily characterized as a function of their synthetic substrate specificity as well as heat and sulfhydrl group lability $(17,23-26)$. Cathepsin A, originally referred to as the "hemoglobin splitting" enzyme, has been identified in a variety of tissues including leukocyte lysosomes $(17,23,26)$. The enzyme loses activity on moderate heating and does not require cysteine for activation nor is it inhibited by iodoacetamide. In addition, cathepsin A specifically hydrolyzes the synthetic substrate $N-\mathrm{CBZ}-\alpha$-Lglutamyl-L-tyrosine at $\mathrm{pH} 5$ (23). According to these criteria, as delineated by Fruton (23), at least one of the enzyme activities in the peak $4 \mathrm{ma}$ terial can be regarded as platelet cathepsin A. On the basis of cysteine potentiation studies on peak 4 material it is unlikely that cathepsins $B$ or $E$ were present in the enzyme preparation. The complete loss of peak 4 protease activity with gentle heating to $60^{\circ} \mathrm{C}$ for $15 \mathrm{~min}$ and the lack of activity using $N$-acetyl-tyrosine ethyl ester as substrate make it unlikely that cathepsin $\mathrm{C}$ was present in this fraction. Cathepsin $\mathrm{D}$ is optimally active at $\mathrm{pH} 2.8$ and it is thus unlikely that this enzyme was present in the peak 4 solution. It should be noted that these conclusions are inferential and it is possible that other cathepsin activities were originally present but underwent denaturation in the process of preparation of the platelet protein.

The $\mathrm{pH}$ optimal studies demonstrated a broad alkaline range of enzyme activity in peak 4 particularly with respect to the alpha casein and fibrinogen substrates. Neutral proteinase activity has been previously described in the hemoglobin-free stroma of normal human red cells (27). These activities are enhanced by the presence of $\mathrm{Fe}^{++}, \mathrm{Zn}^{++}$, or $\mathrm{Mn}^{++}(27)$. This potentiation was not observed when peak 4 was tested against alpha casein and fibrinogen in the presence of these salts. One of the previously reported red cell enzymes, erythrocyte proteinase III, was not stimulated by metal 
ions; however, maximum activity was noted at $\mathrm{pH}$ 3.2. It would thus appear that the peak 4 enzyme preparation had properties which differed from those described in human red cells.

Human leukocytes contain hydrolytic enzymes which are located primarily in lysosomes. Recent studies suggest that the cathepsins in these subcellular organelles include cathepsin A and probably $\mathrm{D}$ and $\mathrm{E}$ (17). It is of interest that Wasi et al. (17), working with crude extracts of polymorphonuclear lysosomes, demonstrated $49 \%$ inhibition of the cathepsin activity by iodoacetic acid and $28 \%$ stimulation with cysteine. This finding contrasts with our findings on the sulfhydryl lability of the cathepsin activity in the peak 4 solution and might reflect $(a)$ the different character of cathep$\sin \mathrm{A}$ in leukocytes and platelets or $(b)$ the significant contribution of cathepsin $\mathrm{D}$ and $\mathrm{E}$ to the total leukocyte lysosomal cathepsin activity.

Although the data strongly suggest the presence of cathepsin A in platelets these studies do not imply that this is only protease present. The double curve of the $\mathrm{pH}$ optima studies when alpha casein was used as substrate, as well as the alkaline range of activity of the enzyme solution when casein and fibrinogen were used as substrates, suggests the presence of additional enzyme activity. It should be noted that neutral di- and tripeptidases have previously been demonstrated in platelet extracts (28). It is not possible from our studies to clearly define the actual number of proteases involved. Further subfractionation of the peak 4 material may provide additional information.

The fact that platelets possess a potent fibrinogenolytic enzyme(s) raises the possibility that intracellular protease activity may play a role in the hemostatic process. It has been previously demonstrated that approximately $10 \%$ of platelet protein is fibrinogen (29). Thus the platelet plug which forms in apposition to damaged endothelial surfaces constitutes a small area with a relatively high concentration of fibrinogen. In addition, fibrin formation takes place at the periphery of the plug during the later stages of hemostasis (30). Electron microscopic evidence indicates that intracellular granule lysis occurs concomitant with these processes. Activation of platelet proteolytic activities during these events may initiate the stage of platelet plug dissolution. This nonplasmin protease system active in the interstices of the plug would complement the generation of plasmin (adjacent to the peripheral fibrin network) after the activation of plasminogen. The possibility of other physiologic consequences after the activation of intracellular platelet proteolytic activity should be considered. Previous studies have shown that platelets can be considered as initiators of an inflammatory response leading to increased vascular permeability (30). The intracellular hydrolytic events which follow platelet aggregation may be important factors in phlogistic tissue responses comparable to those seen in leukocyte exudate formation.

\section{ACKNOWLEDGMENTS}

We wish to acknowledge the helpful suggestions of Dr. Aaron Marcus.

This work was supported in part by a research grant from the U. S. Public Health Service C-1905.

\section{REFERENCES}

1. DeDuve, C. 1963. The Lysosomal Concept in Lysosomes. A. V. S. Reuck and M. P. Camerson, editors. Little, Brown and Co., Boston. 1.

2. Hirsch, J. G., and Z. A. Cohn. 1960. Degranulation of polymorphonuclear leucocytes following phagocytosis of microorganisms. J. Exptl. Med. 112: 1005.

3. Marcus, A. J., D. Zucker-Franklin, L. B. Safier, and H. L. Ullman. 1966. Studies on human platelet granules and membranes. J. Clin. Invest. 45: 14.

4. Rodman, N. F., and R. C. Mason. 1967. Plateletplatelet interaction. Relationship to hemostasis and thrombosis. Federation Proc. 26: 95.

5. Nachman, R. L., A. J. Marcus, and L. B. Safier. 1967. Platelet thrombosthenin: subcellular localization and function. J. Clin. Invest. 46: 1380.

6. Siqueira, M., and R. A. Nelson, Jr. 1961. Platelet agglutination by immune complexes and its possible role in hypersensitivity. J. Immunol. 86: 516.

7. Nachman, R. L. 1965. Immunologic studies of platelet protein. Blood. 25 : 703.

8. Nachman, R. L., A. J. Marcus, and D. ZuckerFranklin. 1967. Immunologic studies of proteins associated with subcellular fractions of normal human platelets. J. Lab. Clin. Med. 69: 651.

9. Davis, B. J. 1964. Disc electrophoresis. Ann. N. Y. Acad. Sci. 121: 404.

10. Chramback, A., R. A. Reisfeld, M. Wyckoff, and J. Zaccari. 1967. A procedure for rapid and sensitive staining of protein fractionated by polyacrylamide gel electrophoresis. Anal. Biochem. 20: 150

11. Anson, M. L. 1940. The purification of cathepsin. J. Gen. Physiol. 23: 695.

12. Kabat, E. A., and M. M. Mayer. 1961. Experimental Immunochemistry. Charles C Thomas, Springfield, IIl. 2nd edition. 557 . 
13. Ellis, P. A. 1961. A new universal buffer system. Nature. 191: 1098.

14. McIlvaine, T. C. 1921. A buffer solution for colorimetric comparison. J. Biol. Chem. 49: 183.

15. Lineweaver, H. and D. Burk. 1934. The determination of enzyme dissociation constants. J. Am. Chem. Soc. 56: 658 .

16. Tallan, H. H., M. E. Jones, and J. S. Fruton. 1952. On the proteolytic enzyme of animal tissues. X. Beef cathepsin C. J. Biol. Chem. 194: 793.

17. Wasi, S., R. K. Murray, D. R. L. Macromoue, and H. Z. Movat. 1966. The role of pmn leukocyte lysosomes in tissue injury, inflammation and hypersensitivity. Brit. J. Exptl. Pathol. 47: 411.

18. Korngold, L., G. van Leeuven, and R. L. Engle, Jr. 1962. Diagnosis of multiple myeloma and macroglobulinemia by the Ouchterlony gel diffusion technique. Ann. N. Y. Acad. Sci. 101: 203.

19. Korngold, L. 1957. The distribution and immunochemical properties of human tissue and tumor antigens. Ann. N. Y. Acad. Sci. 69: 681.

20. Merck Index, 1960. Paul G. Stecher, editor. Merck \& Co., Inc., Rahway, N. J. 218.

21. Holemans, R., and R. Gross. 1961. Fibrinolytic activities present in human-blood platelets. Nature. 189 : 238.

22. Christenson, L. R., and C. M. MacLeod. 1945. A proteolytic enzyme of serum: characterization acti- vation and reaction with inhibitors. J. Gen. Physiol. 28: 559 .

23. Fruton, J. S. 1960. Cathepsins in the Enzymes. P. D. Boyer, H. Lardy, and K. Myrbach, editors. Academic Press, Inc., New York. 4: 233.

24. Iodice, A. A., V. Lorenz, and I. M. Weinstock. 1966. Separation of cathepsins A and D of skeletal muscle. Arch. Biochem. Biophys. 117: 477.

25. Lapresle, C., and T. Webb. 1962. The purification of a proteolytic enzyme, rabbit cathepsin $\mathrm{E}$, and further studies on rabbit cathepsin D. Biochem. J. 84: 455.

26. Press, E. M., R. R. Porter, and J. Cebra. 1960. The isolation and properties of a proteolytic enzyme, cathepsin D, from bovine spleen. Biochem. J. 74: 501.

27. Morrison, W. L., and H. Neurath. 1953. Proteolytic enzymes of the formed elements of human blood: J. Biol. Chem. 200: 39.

28. Kochalaty, W. 1962. Peptidase activity in human platelets. Thromb. Diath. Haemorrhag. 7: 295.

29. Nachman, R. L. 1966. Thrombasthenia: immunologic evidence of a platelet protein abnormality. J. Lab. Clin. Med. 67: 411.

30. Mustard, J. F., M. F. Glyn, T. Hovig, L. Jorgensen, M. A. Packham, E. Nishizawa, and H. C. Roswell. 1967. Platelets, blood coagulation and thrombosis. In Physiology of Hemostasis and Thrombosis. S. A. Johnson and W. H. Seegers, editors. Charles C Thomas, Springfield, Ill. 288. 